\title{
STUDI TENTANG FAKTOR PENYEBAB RENDAHNYA KEMAMPUAN MEMBACA
}

\author{
ICHYATUL AFROM \\ Dosen Prodi Bahasa dan Sastra Indonesia FKIP Universitas Palangkaraya
}

\begin{abstract}
ABSTRAK
Membaca di sekolah dasar merupakan landasan bagi tingkat pendidikan yang lebih tinggi. Sebagai kemampuan yang mendasari tingkat pendidikan selanjutnya, membaca perlu mendapat perhatian pendidik, sebab jika dasarnya tidak kuat pada tahapan pendidikan berikutnya peserta didik akan mengalami kesulitan untuk dapat memperoleh dan memiliki pengetahuan. Kemampuan membaca tidak dapat dilakukan tanpa sarana-sarana yang perlu terutama bahan-bahan bacaan yang baik, minat baca pada anak, dorongan orang tua, (masyarakat). Maka kemampuan membaca merupakan fasilitas yang dapat menjunjung tinggi harkat dan martabat bangsa, tetapi yang menjadi kendala pada kenyataannya sekarang masih rendahnya kemampuan membaca peserta didik dan perlu untuk ditingkatkan terutama dorongan dari orang tua (masyarakat).Penelitian ini bertujuan untuk mengetahui faktor penyebab rendahnya kemampuan membaca peserta didik di Palangkaraya.

Penelitian ini menggunakan metode deskriptif. Populasi dalam penelitian ini adalah 100 orang peserta didik yang mengalami kesulitan dalam membaca Hasil penelitian faktor yang dominan sampai yang sangat dominan rendahnya kemampuan membaca peserta didik, bahwa peserta didik pada saat membaca tidak memperhatikan tanda baca ada $75 \%$. Peserta didik tidak memahami kalimat yang dibacanya ada $60 \%$. Peserta didik tidak lancar membaca ada $10 \%$. Peserta didik pada saat membaca menghilangkan huruf atau kata ada $22 \%$, dan peserta didik kesalahan melafalkan huruf yang bunyinya mirip seperti huruf $b$ dengan $\mathrm{p} 21 \%$.
\end{abstract}

Kata kunci : Rendahnya Kemampuan Membaca.

\begin{abstract}
s
Writing is a complex language skills and should be owned by learners from kindergarten to College. Writing requires skills to read to see what is already written, writing also requires the ability of an understanding of what the contents are written. Sometimes people can speak but cannot write back what was discussed. Otherwise, anyone can write, but cannot discuss his writings. However, there are also people who could speak and write. Influence resulted learners of frequent or intensnya learners visit library is one skilled in writing. Besides skilled concocted learners also gain insight, language, skill and information obtained from books. A positive influence intensity learners visit library consisting of several factors. Among the factors affecting desire to add insight, capability of language, and ably magicians, personal and by the pleasure appears as intrinsic motivators self when visiting the library. Aside from learners often visit the library. A collection of books at home has some role in the tracery of insight and skill in making a child authorship. The existence of the book readings at home then it would add to the learner the opportunity to always read in the library that is provided in the school. These factors are obtained based on the question form is deployed to collect data support in strengthening hiopesis received in this research. The results of this research show that there were significant effects between the intensity of a visit to the library to write skills learners. The more often the students visiting the library is getting better and is skilled in writing. With a proven testing the hypothesis that $Y=44,470,38 X$. In addition to the value of $(b)$ the positive values of $b$ are also larger dar $r$ table in the sample as many as 100 people i.e. 0,195 . B calculate the value of 0.38 \& gt; $r$ tables there, meaning 0,195 positive influence the intensity of a visit to the library to write skills learners.
\end{abstract}

Keywords: writing, writing, library 


\section{PENDAHULUAN}

\section{Latar Belakang}

Salah satu aspek yang memegang peranan penting dalam mata pelajaran Bahasa Indonesia yakni pembelajaran membaca. Tanpa memiliki kemampuan membaca yang memadai sejak dini, peserta didik akan mengalami kesulitan belajar dikemudian hari. Sebab dengan membaca peserta didik akan dapat memperoleh pengetahuan yang sangat bermanfaat bagi pertumbuhan dan perkembangan daya nalar, sosial dan emosionalnya.

Membaca di sekolah dasar merupakan landasan bagi tingkat pendidikan yang lebih tinggi. Sebagai kemampuan yang mendasari tingkat pendidikan selanjutnya, membaca perlu mendapat perhatian pendidik, sebab jika dasarnya tidak kuat pada tahapan pendidikan berikutnya peserta didik akan mengalami kesulitan untuk dapat memperoleh dan memiliki pengetahuan. Kemampuan membaca tidak dapat dilakukan tanpa sarana-sarana yang perlu terutama bahan-bahan bacaan yang baik, minat baca pada anak, dorongan orang tua, (masyarakat). Maka kemampuan membaca merupakan fasilitas yang dapat menjunjung tinggi harkat dan martabat bangsa, tetapi yang menjadi kendala pada kenyataannya sekarang masih rendahnya kemampuan membaca peserta didik dan perlu untuk ditingkatkan terutama dorongan dari orang tua (masyarakat).

Setelah melakukan observasi di beberapa sekolah, baik itu SD, SMP, maupun SMA di Palangkaraya diketahui bahwa kemampuan membaca peserta didik ini sudah relativ baik, tetapi meskipun demikian, masih ditemukan peserta didik yang mempunyai masalah dalam keterampilan membaca.

Sehubungan dengan uraian tersebut, peneliti tertarik untuk mengangkat judul "Studi Tentang Faktor Penyebab Rendahnya Kemampuan Membaca".

Berdasarkan latar belakang yang telah diuraikan, teridentifikasi beberapa masalah sebagai berikut :

1. Ditemukan kemampuan membaca peserta didiknya pada mata pelajaran Bahasa Indonesia masih rendah.

2. Peserta didik mendapat nilai membaca di bawah kriteria ketuntasan minimum.

Menghindari luasnya masalah yang diteliti, maka peneliti memberikan batasan masalah sebagai berikut Penelitian ini dibatasi pada faktor penyebab rendahnya kemampuan peserta didik dalam membaca di kota Palangkaraya.

Berdasarkan uraian pada latar belakang, maka dapat dirumuskan permasalahan penelitian sebagai berikut: Apa faktor yang menyebabkan rendahnya kemampuan membaca peserta didik di Palangkaraya.?

\section{KAJIAN TEORI}

\section{Analisis Teoritis}

\section{Pembelajaran Bahasa Indonesia}

a. Pengertian Pelajaran Bahasa Indonesia di Sekolah Dasar

Bahasa Indonesia adalah bahasa resmi Republik Indonesia dan bahasa persatuan Bangsa Indonesia Bahasa Indonesia diresmikan penggunaannya setelah Proklamasi Kemerdekaan Indonesia, tepatnya sehari 
sesudahnya, bersamaan dengan mulai berlakunya konstitusi.

Pembelajaran bahasa Indonesia di sekolah diharapkan membantu peserta didik mengenal dirinya, budayanya dan budaya orang lain, mengemukakan gagasan dan perasaan, berpartisipasi dalam masyarakat yang menggunakan bahasa tersebut dan menemukan serta menggunakan kemampuan analitis dan imajinatif yang ada dalam dirinya.

b. Tujuan Pembelajaran Bahasa Indonesia

Dengan pembelajaran bahasa Indonesia agar peserta didik diharapkan memiliki kemampuan sebagai berikut:

1) Peserta didik diharapkan mampu menggunakan bahasa Indonesia secara baik dan benar serta dapat berkomunikasi secara efektif dan efisien baik secara lisan maupun tulis sesuai dengan etika yang berlaku.

2) Peserta didik bangga dan menghargai bahasa Indonesia sebagai bahasa negara dan bahasa pemersatu bangsa Indonesia.

3) Peserta didik mampu memahami bahasa Indonesia serta dapat menggunakannya dengan tepat dan kreatif untuk berbagai tujuan.

4) Peserta didik mampu menggunakan bahasa Indonesia untuk meningkatkan kemampuan intelektual, serta kematangan emosional dan sosial.

5) Peserta didik dapat membaca dan memanfaatkan karya sastra untuk memperluas wawasan, memperhalus budi pekerti, serta meningkatkan pengetahuan dan kemampuan berbahasa.

6) Peserta didik diharapkan dapat menghayati bahasa dan sastra Indonesia serta menghargai dan bangga terhadap sastra Indonesia sebagai intelektual Indonesia.

\section{Membaca Permulaan}

Membaca permulaan dalam pengertian teori keterampilan membaca permulaan yang dimaksud oleh Abidin (2010:114) yaitu membaca yang menekankan pada proses penyedian membaca secara menikal. Membaca permulaan yang menjadi acuan adalah membaca merupakan proses recording dan decoding.

\section{Pengertian Membaca Permulaan}

Membaca permulaan merupakan tahapan proses belajar membaca bagi peserta didik sekolah dasar kelas awal. Peserta didik belajar untuk memperoleh kemampuan dan menguasai teknik-teknik membaca dan menangkap isi bacaan dengan baik. Oleh karena itu pendidik perlu merancang pembelajaran membaca dengan baik sehingga mampu menumbuhkan kebiasan membaca sebagai suatu yang menyenangkan.

Adapun pengertian membaca permulaan menurut para ahli, adalah sebagai berikut :

1. Menurut Aderson (20 mei 2012) membaca permulaan merupakan "suatu proses yang bersifat fisik dan psikologis. Proses yang bersifat fisik berupa kegiatan mengamati tulisan. Proses psikologis berupa kegiatan berpikir dan mengolah informasi.

2. Menurut Sri Nuryati (2002:5) Membaca permulaan merupakan "suatu proses keterampilan dan kognitif. Proses keterampilan menunjuk pada pengenalan dan penguasaan lambang-lambang fonem, sedangkan proses kognitif menunjuk pada penggunaan lambang-lambang fonem yang 
sudah dikenal untuk memahami makna suatu kata atau kalimat"

Berdasarkan pendapat tersebut, bahwa kemampuan membaca merupakan kemampuan yang harus dimiliki oleh peserta didik untuk dasar membaca lanjut. Membaca permulaan merupakan proses belajar untuk mengenal dan menguasai lambang-lambang suatu kata atau kalimat.

\section{Tujuan Membaca Permulaan}

Pembelajaran membaca permulaan diberikan pada kelas I dan kelas II. Tujuannya adalah supaya peserta didik memiliki kemampuan memahami dan menyuarakan tulisan dengan intonasi yang benar, sebagai dasar untuk dapat membaca lanjut. Tujuan membaca permulaan tidak terlepas dari tujuan pendidikan pada umumnya dan tujuan pengajaran pada khususnya. Tujuan pengajaran membaca permulaan pada dasarnya adalah memberikan bekal pengetahuan dan kemampuan peserta didik untuk menguasai tehnik-tehnik membaca dan menangkap isi bacaan dengan baik dan benar.

Pelaksanaan membaca permulaan di kelas I dan kelas II Sekolah Dasar dilakukan dalam dua tahap, yaitu membaca periode tanpa buku dan membaca dengan menggunakan buku. Pembelajaran membaca tanpa buku dilakukan dengan cara mengajar dengan menggunakan media atau alat peraga selain buku misalnya kartu gambar, kartu huruf, kartu kata dan kartu kalimat. Pembelajaran membaca dengan buku merupakan kegiatan membaca dengan menggunakan buku sebagai bahan pelajaran.

Adapun tujuan membaca permulaan menurut para ahli, adalah sebagai berikut :
1. Depdikbud, (2000 : 4) yaitu agar "peserta didik dapat membaca kata-kata dan kalimat sederhana dengan lancar dan tepat".

2. Rita Wati (2003:46) tujuan pengajaran membaca permulaan adalah "agar peserta didik dapat membaca kata-kata dan kalimat sederhana dengan lancar dan tepat. Pengajaran membaca permulaan disesuaikan dengan kemampuan dan perkembangan kejiwaan peserta didik".

Berdasarkan pendapat tersebut maka dapat disimpulkan bahwa tujuan membaca permulaan adalah agar peserta didik dapat membaca katakata dan kalimat sederhana dengan lancar.

\section{a. Faktor-Faktor Yang Mempengaruhi Kemampuan Membaca Permulaan Peserta Didik}

Faktor yang mempengaruhi rendahnya kemampuan membaca permulaan peserta didik yang dipengaruhi dari dalam diri peserta didik (internal) dan ada juga yang muncul, karena pengaruh yang berasal dari luar diri peserta didik (eksternal).

1) Faktor internal yang mempengaruhi rendahnya kemampuan membaca permulaan yaitu faktor yang disebabkan dari dalam diri peserta didik terutama minat baca yang kurang dibiasakan untuk belajar membaca. Hal ini menyebabkan rendahnya kemampuan membaca peserta didik. Hal tersebut sejalan dengan pendapat Muhibbin syah (2002:166) yang menyatakan bahwa "pengaruh rendahnya kemampuan membaca peserta didik yaitu minat baca yang kurang dan kebiasaan belajar membaca peserta didik yang kurang hal ini menyebabkan kemampuan membaca peserta didik tidak terlatih". 
2) Faktor eksternal yang mempengaruhi kemampuan membaca peserta didik yaitu terdiri dari :

a) Keadaan lingkungan keluarga

Keadaan keluarga yang bekerja sebagai pedagang di pasar memiliki waktu yang sangat sedikit ketika berada di rumah untuk membimbing anaknya belajar membaca. Hal ini berpengaruh terhadap pola belajar anak karena kesibukan orang tua dalam bekerja di pasar yaitu sebagai pedagang sehingga tiap hari waktu luang sangat minim bahkan hampir tidak ada untuk melakukan kegiatan baca. Anak yang setiap hari jarang melihat keluarganya melakukan kegiatan membaca secara umum anak juga kurang memiliki kegemaran dalam membaca

$\mathrm{Hal}$ di atas sejalan dengan pendapat Hendrariahdo (16 juni 2012) yang menyatakan bahwa: "Keadaan lingkungan keluarga juga menentukan dalam pembentukan karakter minat membaca pada anak. Anak yang berasal dari keluarga yang kurang minat membaca akan berpengaruh negatif terhadap kemampuan membaca pada anak".

b) Keadaan ekonomi orang tua

Keadaan ekonomi orang tua yang menengah ke bawah akan berpengaruh untuk kemampuan membaca peserta didik karena keadaan ekonomi orang tua yang menengah ke bawah akan menyebabkan rendahnya kemampuan daya beli orang tua untuk membeli buku bacaan sebagai penunjang belajar membaca anaknya di rumah. Hal ini menyebabkan peserta didik kesulitan dalam belajar membaca. Anak yang tidak memiliki buku bacaan secara umum anak juga jarang melakukan kegiatan membaca.

b. Kesulitan Membaca
Menurut Khusnin (2006:25) faktor yang menyebabkan peserta didik kesulitan membaca adalah :

1) Kurang mengenal huruf.

Kesulitan yang berupa ketidakmampuan peserta didik mengenal huruf-huruf. Ketidak jelasan peserta didik dalam melafalkan sebuah huruf sering terjadi khususnya pada huruf [p], [b], [d], [t], [c], [v].

2) Membaca kata demi kata

Peserta didik yang mengalami kesulitan jenis kesulitan ini biasanya berhenti setelah membaca sebuah kata, tidak segera diikuti dengan kata yang berikutnya. Membaca kata demi kata sering kali disebabkan oleh gagal memahami makna kata dan kurang lancar membaca.

3) Tidak menguasai tanda baca

Peserta didik sering melakukan pemenggalan kata (berhenti membaca) pada tempat yang tidak tepat atau tidak memperhatikan huruf atau kata.

4) Penghilangan huruf atau kata

Kesulitan penghilangan ini adalah peserta didik menghilangkan (tidak dibaca) satu huruf, kata dari teks yang dibacanya. Penghilangan ini disebabkan oleh ketidak mampuan peserta didik mengucapkan hurufhuruf yang membentuk kata.

5) Pengulangan kata

Kebiasaan peserta didik sering mengulang kata atau frase dalam membaca hal ini disebabkan oleh faktor tidak mengenal kata dan kurang menguasai huruf.

Hal ini sejalan dengan pendapat Abdurahman (dalam Meny wati 2010:13) faktor kesulitan membaca disebabkan oleh hal-hal sebagai berikut 
1. Peserta didik kurang mengenal huruf.

2. Peserta didik tidak memahami kalimat yang dibacanya.

3. Peserta didik tidak lancar membaca

4. Peserta didik kesalahan melafalkan huruf yang bunyinya mirip, seperti: bunyi huruf $b$ dengan p.

5. Pesera didik tidak menguasai tanda baca.

Berdasarkan pendapat di atas bahwa yang menyebabkan peserta didik kesulitan membaca permulaan karena peserta didik itu disebabkan karena peserta didik tidak mampu mengucapkan huruf-huruf yang membentuk kata, dan saat membaca mengulang kata karena peserta didik tidak mengenal kata atau kurang menguasai huruf yang ada di dalam teks bacaan.

\section{Kemampuan membaca pemahaman}

Menurut Sadler menyatakan, membaca tidak hanya sekedar memasangkan bunyi dengan huruf atau belajar kata-kata, membaca melibatkan pemahaman, memahami apa yang dibaca, apa maknanya, apa yang diimplikasikan.

Membaca pemahaman berkaitan erat dengan usaha memahami hal-hal penting dari apa yang dibacanya. Yang dimaksud membaca pemahaman atau komprehensi adalah kemampuan membaca untuk mengerti ide pokok, detail penting, dan seluruh pengertian. Pemahaman ini berkaitan erat dengan kemampuan mengingat bahan yang dibacanya.

Berdasarkan pengertian tersebut, ada tiga hal atau tiga elemen dalam membaca pemahaman , yaitu:

1. Pengetahuan dan pengalaman yang telah dimiliki tentang topik.

2. Menghubungkan pengetahuan dan pengalaman dengan teks yang akan dibaca.
3. Proses pemerolehan makna secara aktif sesuai dengan pandangan yang dimiliki.

Usaha efektif untuk memahami dan mengingat lebih lama dapat dilakukan dengan:

a. Mengorganisasikan bahan yang dibacanya dalam kaitan yang mudah dipahami.

b. Mengaitkan fakta yang satu dengan fakta yang lain.

\section{METODOLOGI PENELITIAN}

\section{Metode Penelitian}

Penelitian ini menggunakan metode deskriptif, penelitian deskriptif merupakan penelitian yang dimaksudkan untuk mengumpulkan informasi mengenai status suatu gejala yang ada, yaitu keadaan gejala menurut apa adanya pada saat penelitian dilakukan.

Menurut Moh. Nazir (2005:54) berpendapat bahwa :

Metode deskriptif adalah suatu metode dalam meneliti status sekelompok manusia, suatu objek, suatu set kondisi, suatu sistem pemikiran ataupun suatu kelas peristiwa pada masa sekarang. Tujuan dari penelitian deskriptif ini adalah untuk membuat deskriptif, gambaran atau lukisan secara sistematis, faktual dan akurat mengenai fakta-fakta, sifat-sifat serta hubungan antara fenomena yang diselidiki.

Pada bagian ini peneliti mengobservasi kemampuan membaca dengan memperhatikan aspek-aspek :

1. Peserta didik yang kurang mengenal huruf.

2. Peserta didik tidak memahami kalimat yang dibacanya

3. Peserta didik tidak lancer membaca.

4. Peserta didik kesuliatan dalam merangkai huruf 
5. Kesalahan melafalkan hurup $b$ dan $p$.

6. Penghilangan huruf atau kata.

pengumpulan data dengan observasi terhadap

7. Tidak memperhatikan tanda baca.

\section{Deskripsi Hasil Penelitian}

\section{Penyajian Data}

Hasil analisis Studi Tentang Rendahnya 100 orang peserta didik.

Pada bagian ini akan dibuat tabel hasil observasi peserta didik. Adapun tabel hasil observasi Kemampuan Membaca Peserta Didik di peserta didik adalah sebagai berikut :

Palangkaraya yang diperoleh melalui hasil

Tabel 5. Hasil Observasi Faktor Dominan Rendahnya Kemampua Membaca Peserta Didik di Palangkaraya

\begin{tabular}{|c|c|c|c|c|c|c|}
\hline No & Indikator & Aspek Yang di Nilai & $\begin{array}{l}\text { Frekuensi } \\
\text { Ya }\end{array}$ & $\%(\mathrm{Ya})$ & $\begin{array}{l}\text { Frekuensi } \\
\text { Tidak }\end{array}$ & $\begin{array}{c}\% \\
\text { Tidak }\end{array}$ \\
\hline 1 & $\begin{array}{l}\text { Peserta didik kurang } \\
\text { mengenal huruf, } \\
\text { bunyi, bahasa, dan } \\
\text { bentuk kalimat }\end{array}$ & $\begin{array}{l}\text { - Peserta didik kurang } \\
\text { mengenal huruf }\end{array}$ & 14 & $14 \%$ & 86 & $86 \%$ \\
\hline 2 & $\begin{array}{l}\text { Peserta didik tidak } \\
\text { memahami kalimat } \\
\text { yana dibacanya }\end{array}$ & $\begin{array}{lll}\text { - Peserta } & \text { didik } & \text { tidak } \\
\text { memahami } & \text { kalimat } & \text { yang } \\
\text { dibacanya } & & \end{array}$ & 60 & $60 \%$ & 40 & $40 \%$ \\
\hline 3 & $\begin{array}{l}\text { Peserta didik tidak } \\
\text { lancar membaca }\end{array}$ & $\begin{array}{l}\text { - Peserta didik tidak lancar } \\
\text { membaca } \\
\text { - Peserta didik kesulitan } \\
\text { merangkai huruf. }\end{array}$ & $\begin{array}{l}10 \\
20\end{array}$ & $\begin{array}{l}10 \% \\
20 \%\end{array}$ & $\begin{array}{l}90 \\
80\end{array}$ & $\begin{array}{l}90 \% \\
80 \%\end{array}$ \\
\hline 4 & $\begin{array}{lr}\text { Peserta } & \text { didik } \\
\text { kesalahan } & \\
\text { melafalkan huruf } & \text { hang bunyinya mirip } \\
\text { yang } & \text { seperti huruf } \quad \text { b } \\
\text { dengan p. } & \end{array}$ & $\begin{array}{l}\text { - Peserta didik kesalahan } \\
\text { melafalkan huruf yang } \\
\text { bunyinya mirip seperti } \\
\text { hurup b dengan p. } \\
\text { - Peserta didik pada saat } \\
\text { membaca menghilangkan } \\
\text { huruf atau kata }\end{array}$ & 22 & $21 \%$ & 78 & $78 \%$ \\
\hline 5 & $\begin{array}{lr}\text { Peserta didik } & \text { tidak } \\
\text { menguasai } & \text { tanda } \\
\text { baca } & \end{array}$ & $\begin{array}{l}\text { - Peserta didik pada saat } \\
\text { membaca } \\
\text { memperhatikan } \\
\text { baca. }\end{array}$ & 75 & $75 \%$ & 25 & $25 \%$ \\
\hline
\end{tabular}


Dari penjelasan di atas, faktor penyebab rendahnya kemampuan membaca peserta didik di Palangkaraya dapat dikategorikan sebagai berikut :

1. Dari 100 peserta didik, diketahui sebanyak 14 peserta didik (14\%) menjawab "Ya" bahwa mereka kurang mengenal huruf dan sebanyak 86 peserta didik (86\%) yang menjawab "Tidak". Hal tersebut berarti $14 \%$ peserta didik menyatakan mereka kurang mengenal huruf, data tersebut termasuk kategori cukup dominan. Hal tersebut terlihat ketika peserta didik terhenti membaca, dikarenakan tidak mengetahui bunyi dari huruf yang ada dalam bacaan. Bunyi huruf yang sering tidak dikenal adalah gabungan sy, kh, f, dan z.

2. Dari 100 peserta didik, diketahui sebanyak 60 peserta didik $(60 \%)$ menjawab "Ya" bahwa mereka tidak memahami kalimat yang dibacanya dan sebanyak 40 peserta didik (40\%) yang menjawab "Tidak". Hal tersebut berarti $40 \%$ peserta didik menyatakan mereka tidak memahami kalimat yang dibacanya, data tersebut termasuk kategori sangat dominan dan kebanyakan didominasi oleh peserta didik di SD. Hal tersebut terlihat ketika peserta didik membaca, mereka hanya membaca saja tanpa mengetahui maksud dan makna dari kalimat yang dibacanya

3. Dari 100 peserta didik, diketahui sebanyak 10 peserta didik (10\%) menjawab "Ya" bahwa mereka tidak lancar membaca dan sebanyak 90 peserta didik (90\%) yang menjawab "Tidak". Hal tersebut berarti 10\% peserta didik menyatakan mereka tidak lancar membaca, data tersebut termasuk kategori dominan. Hal tersebut terlihat ketika peserta didik masih terbata-bata dalam membaca bacaan.

4. Dari 100 peserta didik, diketahui sebanyak 20 peserta didik (20\%) menjawab "Ya" bahwa mereka kesulitan merangkai huruf dan sebanyak 80 peserta didik $(80 \%)$ yang menjawab "Tidak". Hal tersebut berarti $20 \%$ peserta didik menyatakan mereka kesulitan merangkai huruf, data tersebut termasuk kategori cukup dominan. Hal tersebut terlihat ketika peserta didik masih kesulitan dalam menyatuka suku-suku kata dalam bacaan.

5. Dari 100 peserta didik, diketahui sebanyak 21 peserta didik (21\%) menjawab "Ya" bahwa mereka bingung membaca huruf yang bunyinya mirip seperti huruf $b$ dengan $p$ dan sebanyak 79 peserta didik (79\%) yang menjawab "Tidak". Hal tersebut berarti $21 \%$ peserta didik menyatakan mereka bingung membaca huruf yang bunyinya mirip seperti huruf $b$ dengan $p$, data tersebut termasuk kategori dominan. Hal tersebut terlihat ketika peserta didik membaca ditemukan peserta didik kesulita membedakan bunyi huruf $b$ dan p pada kata " bapak dan babak".

6. Dari 100 peserta didik, diketahui sebanyak 22 peserta didik (22\%) menjawab "Ya" bahwa mereka pada saat membaca menghilangkan huruf atau kata dan sebanyak 78 peserta didik (78\%) yang menjawab "Tidak". Hal tersebut berarti $22 \%$ peserta didik menyatakan mereka pada saat membaca menghilangkan huruf atau kata, data tersebut termasuk kategori dominan. Hal tersebut terlihat ketika peserta didik 
membaca bacaan, pada bacaan "sukarelawan" di baca "sukrawan".

7. Dari 100 peserta didik, diketahui sebanyak 75 peserta didik (75\%) menjawab "Ya" bahwa mereka pada saat membaca tidak memperhatikan tanda baca dan sebanyak 25 peserta didik (25\%) yang menjawab "Tidak". Hal tersebut berarti $75 \%$ peserta didik menyatakan mereka pada saat membaca tidak memperhatikan tanda baca, data tersebut termasuk kategori sangat dominan. Hal tersebut terlihat ketika peserta didik tidak berhenti ketika ada tanda baca koma (,) ketika membaca bacaan.

\section{KESIMPULAN}

Berdasarkan hasil penelitian dan analisis data dapat ditarik simpulan bahwa penyebab rendahnya kemampuan membaca peserta didik kelas di Palangkaraya dalam pembelajaran Bahasa Indonesia yaitu :

1. Tidak memperhatikan tanda baca

2. Tidak memahami kalimat yang dibacanya

3. Peserta didik kurang lancar membaca

4. Menghilangkan huruf atau kata

5. Bingung melafalkan huruf yang bunyinya mirip

\section{SARAN}

1. Bagi kepala sekolah disarankan mampu membuat kebijakan-kebijakan yang berdampak positif dengan mengajak guruguru berdiskusi menyusun strategi pembelajaran sehingga kemampuan membaca peserta didik dapat ditingkatkan menjadi lebih baik lagi.
2. Bagi guru disarankan dapat menyusun strategi pembelajaran misalnya belajar sambil bermain untuk dapat meningkatkan kemampuan membaca peserta didik.

3. Bagi peneliti lain, penlitian ini dapat dijadikan sebagai bahan acuan untuk penelitian lebih lanjut lagi mengenai faktor yang dominan rendahnya kemampuan membaca peserta didik di Palangkaraya.

\section{DAFTAR PUSTAKA}

Abidin, (2010), Pembelajaran Membaca di SD, Jakarta : Depertemen Pendidikan Nasional

Aderson, (20/05/2012), Pengertian Membaca Permulaan. http//ipotes.wordpress. com

Adi Suryanto, (2008), Evaluasi Pembelajaran Di $S D$, Jakarta: Depertemen Pendidikan Nasional.

Ali Hidayat, (2007). Metode Penelitian, Jakarta : Rineka Cipta

Depdiknas, (2006), Peraturan Mentri Pendidikan Nasional Nomor 22 Tahun 2006 Tentang Standar Kompetensi kelas II Semester I, Jakarta : Tim Penulis

Depdiknas (2000), Metodik Khusus Pengajaran Bahasa Indonesia di Sekolah Dasar. Jakarta: Depdiknas Dirjen Dikdasmen.

Hendrariahdo, (16/06/2012), Keadaan lingkungan keluarga. $\quad$ http://www.sabd aspace.org/masalah kemampuan membaca berbahasa Indonesia.

Moh. Nazir, (2005), Metode Penelitian, Bogor Selatan: Ghalia Indonesia Muhammad Amin, (16/06/2012). Metode Suku Kata http://typecet.com/pdt/ pengertian membaca permulaan-bagi anak kelas rendah SD Ihtml

M̄omo, (2002), Pengajaran Membaca Disekolah Dasar, Jakarta: Bumi Angkasa. 
Muhibbin Syah, (2002), Faktor-faktor Yang Mempengaruhi Kemampuan Membaca, Jakarta: Bumi Angkasa.

M. Toha Anggoro, (2003), Metode Penelitian, Jakarta: Universitas Terbuka.

Purwanto, (2000), Metodologi Pengajaran Bahasa Indonesia di Sekolah Dasar. Jakarta: PT Rosda Jayaputra.

Rita Wati, (2003), Struktur Pengajaran Tata Bahasa Indonesia Untuk SMTA. Surabaya. Indah.

Sri Nuryati, (2002), Dasar-dasar Membaca, Jakarta : Bumi Angkasa

Sugiyono, (2006), Statistik Untuk Penelitian. Jakarta: Depdikbud.

Suharsimi Arikunto, (2003), Manajemen Penelitian, Jakarta: Rineka Cipta.

Sumadi Suryabrata, (2006), Metodologi Penelitian. Jakarta: Gramedia.

Sutrisno Hadi, (2000), Metodologi Penelitian, Jakarta : Rineka Cipta.

Tim Penyusun, (2008), Buku Pedoman Penulisan, Skripsi, Palangkaraya; Universitas Muhammadiyah Palangkaraya.

Walgito, (2000), Metode Penelitian, Jakarta : Rineka Cipta 